\title{
An efficient system for in vitro propagation of Bouchea fluminensis (Vell.) Mold. (Verbenaceae)
}

Cristiano Ferrara de Resende ${ }^{1,6}$, Virgínia Fernandes Braga ${ }^{1}$, Cristiane Jovelina da Silva ${ }^{2}$, Paula da Fonseca Pereira ${ }^{2}$, Cleberson Ribeiro ${ }^{3}$, Fátima Regina Gonçalves Salimena ${ }^{4}$ and Paulo Henrique Pereira Peixoto ${ }^{5}$

Received: 7 February, 2013. Accepted: 31 October, 2013

\begin{abstract}
This study aimed to establish and propagate in vitro plants of Bouchea fluminensis, a medicinal species known in Brazil as gervão-falso ("false verbena"), evaluating the influences of different growth regulators on in vitro multiplication and rooting stages, as well as examining ex vitro acclimatization of rooted plants. Explants were established on Murashige and Skoog medium at half strength of salts and vitamins without growth regulators. For multiplication, the explants were subjected to combinations of 6-benzyladenine (BA; 0, 2.5, 5.0 and 7.5 $\mu \mathrm{M}$ ) and $\alpha$-naphthalene-acetic acid (NAA; $0,0.2,0.4$ and $0.6 \mu \mathrm{M})$. The medium found to induce the greatest number of shoot was that containing $5 \mu \mathrm{M}$ of BA (NAA-free). For rooting, we evaluated three auxins (NAA, indole-3-acetic acid and indole-3-butyric acid; 0.1, 0.2, 0.3 and $0.4 \mu \mathrm{M}$ ), as well as a control. No differences were observed between the control and the other treatments. The auxin-free medium was deemed the most suitable, because it ensures the lowest cost in the micropropagation procedures. We obtained $100 \%$ survival of the acclimatized seedlings, and the plants showed normal vegetative and reproductive development, suggesting that the micropropagation did not alter the biological cycle of this species. The results show the importance and potential of micropropagation for biodiversity conservation of Bouchea fluminensis.
\end{abstract}

Key words: micropropagation, biodiversity conservation, Espinhaço Mountain Range

\section{Introduction}

Verbenaceae is one of the five most important families among the eudicots found in the campos rupestres (dry, rocky grasslands) of Brazil, occurring in practically all of the terrestrial ecosystems (Souza \& Lorenzi 2005; Judd et al. 2009). The campos rupestres make up an extremely fragile and low resiliency ecosystem. Once the relationship between the vegetation and the environment has been broken, there are lesser chances of spontaneous regeneration. Due to this fragility, several species are extinct or are headed for extinction (Giulietti et al. 1987).

Despite the known medicinal importance of many species of Verbenaceae (Pascual et al. 2001; Sousa \& Costa 2012), the effects that anthropogenic disturbances have had on the endemic populations of such species remain unknown (Giulietti et al. 2000). Bouchea fluminensis (Vell.) Mold., popularly known as gervão-falso ("false verbena") or gervão-de-folha-grande ("large-leaf verbena"), is a herbaceous plants found in Brazil and Bolivia (Troncoso
1974; Pupo et al. 2008a). The plant is used in traditional medicine for its properties of stimulating and regulating the digestive system (Delaporte et al. 2002), as well as for its anti-inflammatory, antifungal and analgesic effects (Delaporte et al. 2001, 2002; Costa et al. 2003; Falcão et al. 2005; Fenner et al. 2006; Pupo et al. 2008a, 2008b). Chemical studies of $B$. fluminensis have isolated the organic compounds responsible for the pharmacological effects of the species (von Poser et al. 1997; Schuquel et al. 1998; Delaporte et al. 2002).

Although there are numerous studies in the literature dealing with the in vitro cultivation of medicinal plants, there have been few involving species endemic to the Espinhaço Mountain Range of central-eastern Brazil (Peixoto et al. 2006). In vitro cultivation techniques enable the conservation of biodiversity through the mass multiplication of genetically identical plants, as well as the preservation of the germplasm, which is especially important for species threatened with extinction (Arora \& Bhojwani 1989; Sudha \& Seeni 1994; Baskaran \& Jayabalan 2005).

\footnotetext{
${ }^{1}$ Universidade Federal de Juiz de Fora, Instituto de Ciências Biológicas, Departamento de Botânica, Juiz de Fora, MG, Brazil

${ }^{2}$ Universidade Federal de Viçosa, Departamento de Biologia Vegetal, Viçosa, MG, Brazil

${ }^{3}$ Universidade Federal de Viçosa, Centro de Ciências Biológicas, Departamento de Biologia Geral, Viçosa, MG, Brazil

${ }^{4}$ Universidade Federal de Juiz de Fora, Instituto de Ciências Biológicas, Departamento de Botânica, Juiz de Fora, MG, Brazil

${ }^{5}$ Universidade Federal de Juiz de Fora, Instituto de Ciências Biológicas, Departamento de Botânica, Juiz de Fora, MG, Brazil

${ }^{6}$ Author for correspondence: cristianoig2004@hotmail.com
} 
The aim of this work was to examine the in vitro establishment, propagation and rooting, as well as the ex vitro acclimatization, of Bouchea fluminensis plants, a species with known medicinal activity and endemic to the Campos Rupestres.

\section{Material and methods}

\section{In vitro establishment}

After obtaining the appropriate permits from environmental protection agencies, we collected Bouchea fluminensis (Vell.) Mold. plants from the Espinhaço Mountain Range, located in the state of Minas Gerais, Brazil (18 $14^{\circ} 48^{\prime \prime}$ 'S to $19^{\circ} 27^{\prime} 47^{\prime \prime} \mathrm{S} ; 43^{\circ} 36^{\prime} 6^{\prime \prime} \mathrm{W}$ to $\left.43^{\circ} 33^{\prime} 10^{\prime \prime} \mathrm{W}\right)$. The specimens collected were established for vegetative propagation in a nursery. While still in nursery conditions, the plants were sprayed, once a week for one month, with a benomyl solution (Benlate ${ }^{\bullet}, 1.8 \mathrm{mM}$; DuPont, Wilmington, DE, USA).

Thirty nodal segments $(2-3 \mathrm{~cm}$ in height), each containing at least one axillary bud, were removed from the shrubs, and those explants were disinfected in a solution of sodium hypochlorite with $2 \%$ active chlorine, at $30 \%$ $(\mathrm{v} / \mathrm{v})$, for $20 \mathrm{~min}$ and rinsed in sterile distilled water. The explants were inoculated onto Murashige and Skoog (MS) medium (Murashige \& Skoog 1962) at half strength of salts and vitamins, supplemented with $30 \mathrm{~g} \mathrm{~L}^{-1}$ of sucrose (Sigma, St. Louis, MO, USA) and $7 \mathrm{~g} \mathrm{~L}^{-1}$ of agar (Sigma), without the addition of growth regulators. The $\mathrm{pH}$ of the culture medium was adjusted to $5.7 \pm 0.1$, after which the cultures were autoclaved for $20 \mathrm{~min}$ at $120^{\circ} \mathrm{C}$ and $1 \mathrm{~atm}$ of pressure.

The explants were inoculated aseptically, in a laminar flow hood (VECO, Campinas, Brazil), in $2.5 \times 15 \mathrm{~cm}$ test tubes, closed with autoclavable polyethylene stoppers and sealed with PVC film tapes $15 \mu \mathrm{m}$ in thickness. The cultures were kept in a growing room at $24 \pm 3^{\circ} \mathrm{C}$, under 40 $\mathrm{W}$ fluorescent lamps-cool-white and Gro-Lux (Sylvania, Danvers, MA, USA), at a 1:1 ratio-with photon flux density of $45 \mu$ moles of photons $\mathrm{m}^{-2} \mathrm{~s}^{-1}$ on a $16 / 8$-h light/dark cycle. Explants were inspected daily for any signs of fungal or bacterial contamination.

\section{In vitro multiplication and rooting}

For the multiplication test, explants consisting of nodal segments (2-3 cm in height) were removed from established in vitro cultures of Bouchea fluminensis (Vell.) Mold. The explants were inoculated onto MS medium, at full strength of salts and vitamins, supplemented with 6-benzyladenine (BA: $0 ; 2.5 ; 5.0$; and $7.5 \mu \mathrm{M}$ ) and $\alpha$-naphthalene-acetic acid (NAA: $0 ; 0.2 ; 0.4$ and $0.6 \mu \mathrm{M}$ ), in all possible combinations, for a total of 16 different treatments, with 10 replicates each.

In the rooting experiment, explants consisting of stem apices were obtained from Bouchea fluminensis (Vell.) Mold. seedlings previously established in vitro. The explants were inoculated onto MS medium, at full strength of salts and vitamins, supplemented with NAA, indole-3-acetic acid (IAA) or indole-3-butyric acid (IBA) at concentrations of 0.1, 0.2, 0.3 and $0.4 \mu \mathrm{M}$, or without supplementation (control), for a total of 13 different treatments, with 10 replicates each. After 40 days of cultivation in vitro, the explants were evaluated on the basis of the number and height of the shoots, as well as on the number of roots.

\section{Statistical analyses}

The experiments were conducted in a completely randomized manner. The count data were normalized with the equation $\sqrt{x+0.5}$, and the measurement data were normalized with the equation $\log (x+1)$. The results were submitted to ANOVA and the Scott-Knott test, both at $5 \%$ probability, using the program SAEG, version 9.1 (http://www.ufv.br/saeg/download.htm).

\section{Ex vitro acclimatization}

Bouchea fluminensis (Vell.) Mold. seedlings elongated and rooted in vitro (average height, $5 \mathrm{~cm}$ ) were acclimatized and reestablished ex vitro. After 45 days of cultivation in vitro, 130 plantlets were removed from the test tubes and their roots were rinsed in running tap water to remove the residual culture medium. Subsequently, they were transplanted in polystyrene trays with 128 cells, containing the substrate (Plantmax Hortaliças $\mathrm{HT}^{\circledast}$; Eucatex, São Paulo, Brazil). The trays were covered with transparent plastic wrap and maintained in a shady environment. For 20 days, the plants were watered every other day by spraying the leaves until the substrate was completely moist. The trays were then transferred to the greenhouse, which has an automated, micro-sprinkler irrigation system (activated twice a day, running for $5 \mathrm{~min}$. each time), and were maintained under $70 \%$ sombrite, where they remained for an additional 20 days. The plants were then transplanted to plant beds-prepared with a mixture of soil, sand and bovine manure (3:2:1; $\mathrm{v} / \mathrm{v} / \mathrm{v})$ - exposed to full sun and irrigated twice a week. In this experiment, the survival rate of the transplanted plants was registered.

\section{Results and discussion}

\section{In vitro establishment of the cultures}

The disinfection and pest control methods employed were quite successful, resulting in a low contamination rate $(<20 \%)$.

\section{In vitro multiplication}

In terms of the number of shoots, significant effects were found only for supplementation with BA $(\mathrm{p}<0.05)$. No significant differences were found for supplementation 
with NAA, at any concentration, or for the combination of BA and NAA (Tab. 1).

Increasing the concentration of $\mathrm{BA}$ to $5.0 \mu \mathrm{M}$ promoted growth in terms of the number of shoots, with a mean of 6.85 shoots/explant. At $7.5 \mu \mathrm{M}$ of BA, there was a reduction in the number of shoots in comparison with that obtained at $5.0 \mu \mathrm{M}$, although the multiplication rate obtained at 7.5 $\mu \mathrm{M}$ was higher than that observed for the control explants and for those supplemented with BA at $2.5 \mu \mathrm{M}$. Therefore, supplementation with $5.0 \mu \mathrm{M}$ of BA can be considered the most suitable treatment for inducing multiple shoots in Bouchea fluminensis, precluding the need to add NAA to the culture medium. Higher concentrations of BA reduced the number of shoots, making it inappropriate for inducing multiplication in explants of this species. In addition, the inclusion of NAA in the culture medium did not present a significant stimulus for the in vitro multiplication of the explants. Consequently, a higher cytokinin/auxin ratio, or even the exclusion of this particular auxin, is recommended for maximizing the in vitro proliferation of adventitious shoots (Skoog \& Miller 1957; Ahmad \& Anis 2011). Results similar to those obtained here have been obtained in studies of Vitex negundo and Vitex trifolia, for which the best treatment for inducing multiple shoots was also found to be BA at a concentration of $5.0 \mu \mathrm{M}$ (Hiregoudar et al. 2006; Ahmad \& Anis 2011). As in the present study, a common feature observed by the authors of those studied was the reduction of the number of shoots in response to higher concentrations of BA. In Glandularia perakii, Marino et al. (2003) observed that the addition of BA decreased the multiplication rate of the explants, even at low concentrations. Unlike what was observed in the present study, in which the addition of NAA did not have a significant influence on the number of shoots, NAA has, in other studies, been shown to affect the growth of cultures, stimulating or inhibiting multiplication. For Lippia alba (Gupta et al. 2001) and Phyla nodiflora (Ahmed et al.2005), the addition of NAA has been reported to have negative effects. However, for Vitex agnus-castus (Balaraju et al. 2008), positive effects were obtained from the addition of NAA. Working with Lippia filifolia, Peixoto et al. (2006) found very high multiplication rates in a medium containing $4.5 \mu \mathrm{M}$ of BA combined with $0.054 \mu \mathrm{M}$ of NAA. However, as in the present study, those authors found that the addition of BA had a positive influence only up to a determined concentration, above which it began to impair the multiplication of the shoots. The discrepant results found in the literature can be attributed to the specific genotypes used, mainly regarding their proliferative capacities, as well as to the varying responses to different growth regulators.

With respect to the size of the shoots, the addition of $\mathrm{BA}$, even at the lowest concentration, reduced the elongation of the explants (Tab. 2). Greater shoot elongation was obtained with $0.2 \mu \mathrm{M}$ of NAA, without BA. These results are typical, as the cytokinins generally stimulate shoot

Table 1. Mean number of shoots in Bouchea fluminensis (Vell.) Mold. explants cultivated in vitro for 40 days, in response to different combinations of 6-benzyladenine and $\alpha$-naphthalene-acetic acid.

\begin{tabular}{|c|c|c|c|c|c|}
\hline \multirow{2}{*}{$\mathrm{BA}(\mu \mathrm{M})$} & \multicolumn{4}{|c|}{$\operatorname{NAA}(\mu \mathrm{M})^{*}$} & \multirow{2}{*}{ BA } \\
\hline & 0 & 0.2 & 0.4 & 0.6 & \\
\hline 0 & $1.2 \mathrm{a}^{1}$ & $1.2 \mathrm{a}$ & $1.3 \mathrm{a}$ & $1.9 \mathrm{a}$ & $1.40 \mathrm{D}$ \\
\hline 2.5 & $5.5 \mathrm{a}$ & $4.1 \mathrm{a}$ & $4.3 \mathrm{a}$ & $5.1 \mathrm{a}$ & $4.75 \mathrm{C}$ \\
\hline 5.0 & $7.8 \mathrm{a}$ & $6.2 \mathrm{a}$ & $7.1 \mathrm{a}$ & $6.3 \mathrm{a}$ & $6.85 \mathrm{~A}$ \\
\hline 7.5 & $5.8 \mathrm{a}$ & $5.6 \mathrm{a}$ & $6.4 \mathrm{a}$ & $6.1 \mathrm{a}$ & $5.72 \mathrm{~B}$ \\
\hline
\end{tabular}

BA - 6-benzyladenine; NAA - $\alpha$-naphthalene-acetic acid.

${ }^{*}$ Means followed by the same lower-case letters in the same row and by the same upper-case letters in the rightmost column do not differ by Scott-Knott test at a probability of $5 \%$.

Table 2. Mean height $(\mathrm{cm})$ of Bouchea fluminensis (Vell.) Mold. shoots cultivated in vitro for 40 days, in response to different combinations of 6-benzyladenine and $\alpha$-naphthalene-acetic acid.

\begin{tabular}{|c|c|c|c|c|c|}
\hline \multirow{2}{*}{$\mathrm{BA}(\mu \mathrm{M})$} & \multicolumn{4}{|c|}{$\operatorname{NAA}(\mu \mathrm{M})^{*}$} & \multirow{2}{*}{ BA } \\
\hline & 0 & 0.2 & 0.4 & 0.6 & \\
\hline 0 & $5.24 \mathrm{~b}^{1}$ & $7.60 \mathrm{a}$ & $6.22 \mathrm{a}$ & $4.86 \mathrm{~b}$ & $5.98 \mathrm{~A}$ \\
\hline 2.5 & $3.61 \mathrm{a}$ & $2.95 \mathrm{a}$ & $3.95 \mathrm{a}$ & $3.70 \mathrm{a}$ & $3.55 \mathrm{~B}$ \\
\hline 5.0 & $2.8 \mathrm{a}$ & $2.97 \mathrm{a}$ & $3.21 \mathrm{a}$ & $3.28 \mathrm{a}$ & $3.06 \mathrm{~B}$ \\
\hline 7.5 & $2.35 \mathrm{a}$ & $2.14 \mathrm{a}$ & $3.39 \mathrm{a}$ & $2.69 \mathrm{a}$ & $2.64 \mathrm{C}$ \\
\hline
\end{tabular}

BA - 6-benzyladenine; NAA - $\alpha$-naphthalene-acetic acid.

${ }^{*}$ Means followed by the same lower-case letters in the same row and by the same upper-case letters in the rightmost column do not differ by Scott-Knott test at a probability of $5 \%$. 
proliferation and yet inhibit elongation (Peddaboina et al. 2006; van Standen et al. 2008). Similar results were obtained for Gmelina arborea (Sukartiningsih et al. 1999) and Lippia junelliana (Juliani Jr. et al. 1999).

In the multiplication stage, the most important characteristics of the cultures are the multiplication rates and the size of the shoots, the formation of roots not being required. In the multiplication experiment, no roots were observed in the treatments including BA (data not shown), a result that coincides with those reported in the literature involving the influence of auxins and cytokinins on the control of organogenesis in vitro (Skoog \& Miller 1957; Ahmad \& Anis 2011).

\section{In vitro rooting}

The number of roots obtained in vitro in Bouchea fluminensis explants exposed to the three auxins tested (IAA, IBA and NAA) can be observed in Tab. 3. Regardless of the auxin used and the auxin concentration, there were no significant differences in comparison with the control, in terms of the number of roots formed (Tab. 3). At higher concentrations, IAA and NAA tended to reduce the number of roots, suggesting that higher auxin concentrations have negative effects on rooting, although that was not the case for IBA. An excess of auxins might stimulate the synthesis of ethylene (Yang \& Hoffman 1984), which increases the formation of calli at the base of the cuttings and inhibits the formation and elongation of the roots.

Although we observed no statistical differences in relation to the use of auxins at the concentrations studied, the number of roots formed was quite satisfactory, enabling the establishment of the plants during the acclimatization stage. The fact that the addition of auxins did not increase the number of roots suggests that the in vitro culture of $\mathrm{Bou}$ chea fluminensis plants during the rooting phase should be performed in the absence of these growth regulators, which, in addition to reducing costs, would prevent the formation of calli at the base of the cuttings. However, rooting has been shown to be stimulated only in culture media supplemented with auxins for Vitex agnus-castus (Balaraju et al. 2008), Clerodendrum serratum (Sharma et al. 2009) and
Vitex negundo (Ahmad \& Anis 2011). Some authors have even reported that the addition of more than one auxin has beneficial effects on root formation (Sukartiningsih et al. 1999; Rani \& Nair 2006). Nevertheless, others have reported efficient rooting in culture media not containing auxins (Sukartiningsih et al. 1999; Juliani Jr. et al. 1999; Gupta et al. 2001; Peixoto et al. 2006). As in the latter studies, we found the addition of auxins to be unnecessary for the rooting of B. fluminensis.

\section{Ex vitro acclimatization}

The seedlings obtained in the in vitro rooting phase were acclimatized in trays filled with Plantmax Hortaliças $\mathrm{HT}^{\oplus}$ (Eucatex), a substrate that presents the necessary structure and nutrients for the initial establishment of the plantlets. The acclimatization was performed successfully, there being no losses during this stage. The survival of $100 \%$ of the plants by transplanting demonstrated that this step is not limiting in the micropropagation of Bouchea fluminensis.

After the initial acclimatization in the greenhouse, the plants were transferred to plant beds, where they were exposed to full sun and completed their development. This step is necessary because the light intensity can affect the morphology and anatomy of plants, making plants grown at lower light intensities more difficult to identify (Milaneze-Gutierre et al. 2003). After five months, the Bouchea fluminensis plants began to exhibit the development of inflorescences. Thirty days after that, the floral buds opened, revealing flowers with characteristics typical of the species, indicating that the biological cycle of the plants was not altered by the in vitro cultivation procedures.

Several studies in the literature have reported losses during acclimatization. Sukartiningsih et al. (1999) obtained 90\% survival in Gmelina arborea, similar to the 95\% obtained for Lippia junelliana (Juliani Jr. et al. 1999) and Lippia alba (Gupta et al. 2001). In Lippia filifolia, Peixoto et al. (2006) obtained a somewhat lower survival rate (85\%). This variation is also explained by differences of specific order and by the conditions under which the plantlets were maintained in vitro.

Table 3. Mean number of roots in Bouchea fluminensis (Vell.) Mold. explants cultivated in vitro for 40 days, in response to different combinations of $\alpha$-naphthaleneacetic acid, indole-3-acetic acid and indole-3-butyric acid.*

\begin{tabular}{cccc}
\hline Concentration $(\mu \mathrm{M})$ & NAA & IAA & IBA \\
\hline 0.0 & $6.1 \mathrm{~A}$ & $6.1 \mathrm{~A}$ & $6.1 \mathrm{~A}$ \\
0.1 & $4.9 \mathrm{~A}$ & $5.1 \mathrm{~A}$ & $4.9 \mathrm{~A}$ \\
0.2 & $5.3 \mathrm{~A}$ & $5.3 \mathrm{~A}$ & $5.5 \mathrm{~A}$ \\
0.3 & $8.0 \mathrm{~A}$ & $6.9 \mathrm{~A}$ & $6.1 \mathrm{~A}$ \\
0.4 & $5.3 \mathrm{~A}$ & $5.8 \mathrm{~A}$ & $6.6 \mathrm{~A}$ \\
\hline
\end{tabular}

NAA - $a$-naphthalene-acetic acid; IAA - indole-3-acetic acid; IBA - indole-3-butyric acid.

${ }^{\star}$ Means followed by the same upper-case letters in the same column do not differ by Scott-Knott test at a probability of $5 \%$. 
Our results allow us to conclude that there was a reduced contamination rate during the establishment in vitro of Bouchea fluminensis explants, showing elevated efficiency of the disinfection and pest control methods used. In the in vitro multiplication stage, we recommend the addition of $5.0 \mu \mathrm{M}$ of BA to promote the formation of multiple shoots, the inclusion of NAA not being necessary. For the in vitro rooting, the cultivation of the seedlings in a culture medium without auxins is the most suitable technique, providing satisfactory rooting without the formation of calli. The survival of the plants during the ex vitro acclimatization was $100 \%$, demonstrating that of $B$. fluminensis plants have a high capacity for re-adaptation to field conditions. Finally, our findings demonstrate that in vitro cultivation of $B$. fluminensis is an efficient propagation technique due to the elevated multiplication rates and the easy acclimatization of the plants. This method could be used in plant biodiversity conservation programs, reducing the risk of extinction of this species.

\section{Acknowledgments}

This study received financial support from the Fundação de Amparo à Pesquisa do Estado de Minas Gerais (FAPEMIG, Foundation for the Support of Research in the State of Minas Gerais) and the Publication Support Program of the Pró-Reitoria de Pesquisa da Universidade Federal de Juiz de Fora (PROPESQ-UFJF, Federal University of Juiz de Fora Dean's Office for Research).

\section{References}

Ahmad, N. \& Anis, M. 2011. An efficient in vitro process for recurrent production of cloned plants of Vitex negundo L. European Journal of Forest Research 130: 135-144.

Ahmed, A.B.A.; Gouthaman, T.; Rao, A.S. \& Rao, M.V. 2005. Micropropagation of Phyla nodiflora (L.) Greene: an important medicinal plant. Iranian Journal of Biotechnology 3: 186-190.

Arora, R. \& Bhojwani, S.S. 1989. In vitro propagation and low temperature storage of Saussurea lappa C.B. Clarke - An endangered medicinal plant. Plant Cell Reports 8: 44-47.

Balaraju, K.; Agastian, P.; Preetamraj, J.P.; Arokiyaraj, S. \& Ignacimuthu, S. 2008. Micropropagation of Vitex agnus-castus, (Verbenaceae) - a valuable medicinal plant. In Vitro Cellular \& Developmental Biology - Plant 44: 436-441.

Baskaran, P. \& Jayabalan, N. 2005. An efficient micropropagation system for Eclipta alba - a valuable medicinal herb. In Vitro Cellular \& Developmental Biology - Plant 41: 532-539.

Costa, V.B.; Coube, C.S.; Marinho, B.G.; Matheus, M.E.; Leitão, S.G. \& Fernandes, P.D. 2003. Anti-inflammatory and analgesic activity of Bouchea fluminensis. Fitoterapia 74: 364-371.

Delaporte, R.H.; Sánchez, G.M.; Cuellar, A.C. \& Mello, J.C.P. 2001. Control de Calidad y Actividad Antiinflamatoria de las Drogas Vegetales Alternanthera brasiliana (L.) Kuntze y Bouchea fluminensis (Vell.) Mold. Acta Farmacéutica Bonaerense 20: 39-46.

Delaporte, R.H.; Sánchez, G.M.; Giuliani, A.; Cuellar, A.C. \& Mello, J.C.P. 2002. Anti-inflammatory activity and lipid peroxidation inhibition of iridoid lamiide isolated from Bouchea fluminensis (Vell.) Mold. (Verbenaceae). Journal of Ethnopharmacology 82: $127-130$
Falcão, H.S.; Lima, I.O.; Santos, V.L.; Dantas, H.F.; Diniz, M.F.F.; Barbosa, J.M. \& Batista, L.M. 2005. Review of the plants with anti-inflammatory activity studied in Brazil. Revista Brasileira de Farmacognosia 15: 381-391.

Fenner, R.; Betti, A.H.; Mentz, L.A. \& Rates, S.M.K. 2006. Plantas utilizadas na medicina popular brasileira com potencial atividade antifúngica. Revista Brasileira de Ciências Farmacêuticas 42: 369-394.

Fundação Biodiversitas. Lista de espécies ameaçadas de extinção do Estado de Minas Gerais, 2005. Disponível em: <http://www.biodiversitas.org.br/cepf/edital/flora_iucn.pdf.>. (Acesso em 27 maio 2011).

Giulietti, A.M.; Harley, R.M.; Queiroz, L.P.; Wanderley, M.G.L. \& Pirani, J.R. 2000. Caracterização e endemismo nos campos rupestres da Cadeia do Espinhaço. Pp. 311-318. In: Cavalcanti, T.B.; Walter, B.M.T. (Eds.). Tópicos atuais de Botânica. Embrapa Recursos Genéticos e Biotecnologia, Sociedade Botânica do Brasil, Brasília.

Giulietti, A.M.; Menezes, N.L.; Pirani, J.R.; Meguro, M. \& Wanderley, M.G. 1987. Flora da Serra do Cipó, Minas Gerais: caracterização e lista das espécies. Boletim de Botânica da Universidade de São Paulo 9: 1-151.

Gupta, S.K.; Khanuja, S.P.S. \& Kumar, S. 2001. In vitro micropropagation of Lippia alba. Current Science 81: 206-210.

Hiregoudar, L.V.; Murthy, H.N.; Bhat, J.G.; Nayeen, A.; Hema, B.P.; Hahn, E.J. \& Paek, K.Y. 2006. Rapid clonal propagation of Vitex trifolia. Biologia Plantarum 50: 291-294.

Judd, W.S.; Campbell, C.S.; Kellogg, E.A.; Stevens, P.F. \& Donoghue, M.J. 2009. Sistemática Vegetal: um enfoque filogenético. Porto Alegre: Artmed. 632 p.

Juliani Jr, H.R.; Koroch, A.R.; Juliani, H.R. \& Trippi, V.S. 1999. Micropropagation of Lippia junelliana (Mold.) Tronc. Plant Cell, Tissue and Organ Culture 59: 175-179.

Marino, C.; Ponce, M.T.; Videla, M.E.; Fioretti, S. \& Cirrincione, M. 2003 Micropropagation of Glandularia perakii Cov. et Schn. (Verbenaceae), a native species with ornamental potential. Biocell 27: 57-60.

Milaneze-Gutierre, M.A.; Mello, J.C.P. \& Delaporte, R.H. 2003. Efeitos da intensidade luminosa sobre a morfo-anatomia foliar de Bouchea fluminensis (Vell.) Mold. (Verbenaceae) e sua importância no controle de qualidade da droga vegetal. Revista Brasileira de Farmacognosia 13: 23-33.

Murashige, T. \& Skoog, F. 1962. A revised medium for rapid growth and bioassay with tobacco tissue culture. Physiologia Plantarum 15: 473-497.

Pascual, M.E.; Slowing, K.; Carretero, E.; Mata, D.S. \& Villar, A. 2001. Lippia: traditional uses, chemistry and pharmacology: a review. Journal of Ethnopharmacology 76: 201-214.

Peddaboina, V.; Thamidala, C. \& Karampuri, S. 2006. In vitro shoot multiplication and plant regeneration in four Capsicum species using thidiazuron. Scientia Horticulturae 107: 117-122.

Peixoto, P.H.P.; Salimena, F.R.G.; Santos, M.O.; Garcia, L.S.; Pierre, P.M.O.; Otoni, W.C. \& Viccini, L.F. 2006. In vitro propagation of endangered Lippia filifolia Mart. \& Schauer ex Schauer. In vitro Cellular \& Developmental Biology - Plant 42: 558-561.

Pupo, S.C.; Davison, G.P.; Martínez-Sánchez, G.; Takemura, O.S. \& Delaporte, R.H. 2008a. Bouchea fluminensis (Vell.) Mold. (Verbenaceae). Revisión Bibliográfica. Acta Farmacéutica Bonaerense 27: 280-285.

Pupo, S.C.; Davison, G.P.; Martinez-Sánchez, G.; Takemura, O.S.; Silva, A.V.; Gonçalves, G.F. \& Delaporte, R.H. 2008b. Avaliação da atividade antiinflamatória crônica do extrato etanólico de Bouchea fluminensis (Verbenaceae). Acta Farmacéutica Bonaerense 27: 364-368.

Rani, D.N. \& Nair, G.M. Effects of plant growth regulators on high frequency shoot multiplication and callus regeneration of an important Indian medicinal plant, Nirgundi (Vitex negundo L.). 2006. In Vitro Cellular \& Developmental Biology - Plant 42: 69-73.

Schuquel, I.T.A.; Malheiros, A.; Sarragiotto, M.H. \& Vidotti, G.J. 1998. Iridoid glucosides from Bouchea fluminensis. Phytochemistry 49: 2409-2411.

Sharma, M.; Rai, S.K.; Purshottam, D.K.; Jain, M.; Chakrabarty, D.; Awasthi, A.; Nair, K.N. \& Sharma, A.K. 2009. In vitro clonal propagation of Clerodendrum serratum (Linn.) Moon (barangi): a rare and threatened medicinal plant. Acta Physiologiae Plantarum 31: 379-383.

Skoog, F. \& Miller, C.O. 1957. Chemical regulation of growth and organ formation in plant tissues cultured in vitro. Symposia of the Society for Experimental Biology 11: 118-231. 
Sousa, E.O. \& Costa, J.G.M. 2012. Genus Lantana: chemical aspects and biological activities. Revista Brasileira de Farmacognosia 22: 1155-1180.

Souza, V.C. \& Lorenzi, H. 2005. Botânica Sistemática: guia ilustrado para identificação das famílias de Angiospermas da flora brasileira, baseado em APG II. Nova Odessa, SP: Instituto Plantarum.

Sudha, G.C. \& Seeni, S. 1994. In vitro multiplication and field establishment of Adhatoda beddomei C.B. Clarke, a rare medicinal plant. Plant Cell Reports 13: 203-207.

Sukartiningsih; Nakamura, K. \& Ide, Y. 1999. Clonal propagation of Gmelina arborea Roxb. by in vitro culture. Journal of Forest Research 4: 47-51.

Troncoso, N.S. 1974. Los géneros de verbenáceas de sudamérica extratropical (Argentina, Chile, Bolívia, Paraguay, Uruguay y Sur de Brasil). Darwiniana 18: 348-50.
Van Standen, E.; Zazimalova, E. \& George, E.F. 2008. Plant growth regulators II: cytokinins, their analogues and antagonists. Pp. 205-226. In: George, E. F.; Hall, M. A. \& De Klerk, G.-J. Plant propagation by tissue culture - Volume 1: The background. Springer, Dordrecht.

Vasconcelos, M.F.; Lopes, L.E.; Machado, C.G. \& Rodrigues, M. 2008. As aves dos campos rupestres da Cadeia do Espinhaço: diversidade, endemismo e conservação. Megadiversidade 4: 221-241.

von Poser, G.L.; Toffoli, M.E.; Sobral, M. \& Henriques, A.T. 1997. Iridoid glucosides substitution patterns in Verbenaceae and their taxonomic implication. Plant Systematics and Evolution 205: 265-267.

Yang, S.F. \& Hoffman, N.E. 1984. Ethylene biosynthesis and its regulation in higher plants. Annual Review of Plant Physiology 35: 155-189. 